\title{
(6) \\ Intraocular bevacizumab in the treatment of choroidal metastases from breast cancer
} OPEN ACCESS

\author{
Kalyan Nadiminti, José Pablo Leone
}

Division of Hematology and Oncology, University of lowa, lowa City, lowa, USA

\section{Correspondence to} Dr José Pablo Leone, jose-leone@uiowa.edu

Accepted 31 May 2016

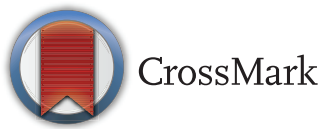

To cite: Nadiminti $\mathrm{K}$ Leone JP. BMJ Case Rep Published online: [please include Day Month Year] doi:10.1136/bcr-2016215719

\section{DESCRIPTION}

We report the case of a 38-year-old woman who was initially diagnosed with stage II oestrogen receptor (ER) positive, progesterone receptor (PR) positive, human epidermal growth factor receptor 2 (HER2) negative infiltrating ductal carcinoma of the breast, in 2013. Breast MRI at that time showed multifocal disease in the right breast. The patient underwent a right mastectomy and axillary lymph node dissection, which revealed pT2 N1a breast cancer. Following this, she received four cycles of docetaxel and cyclophosphamide and adjuvant radiation. At that time, she had declined tamoxifen due to her history of lattice degeneration and concerns of retinal detachment. She was
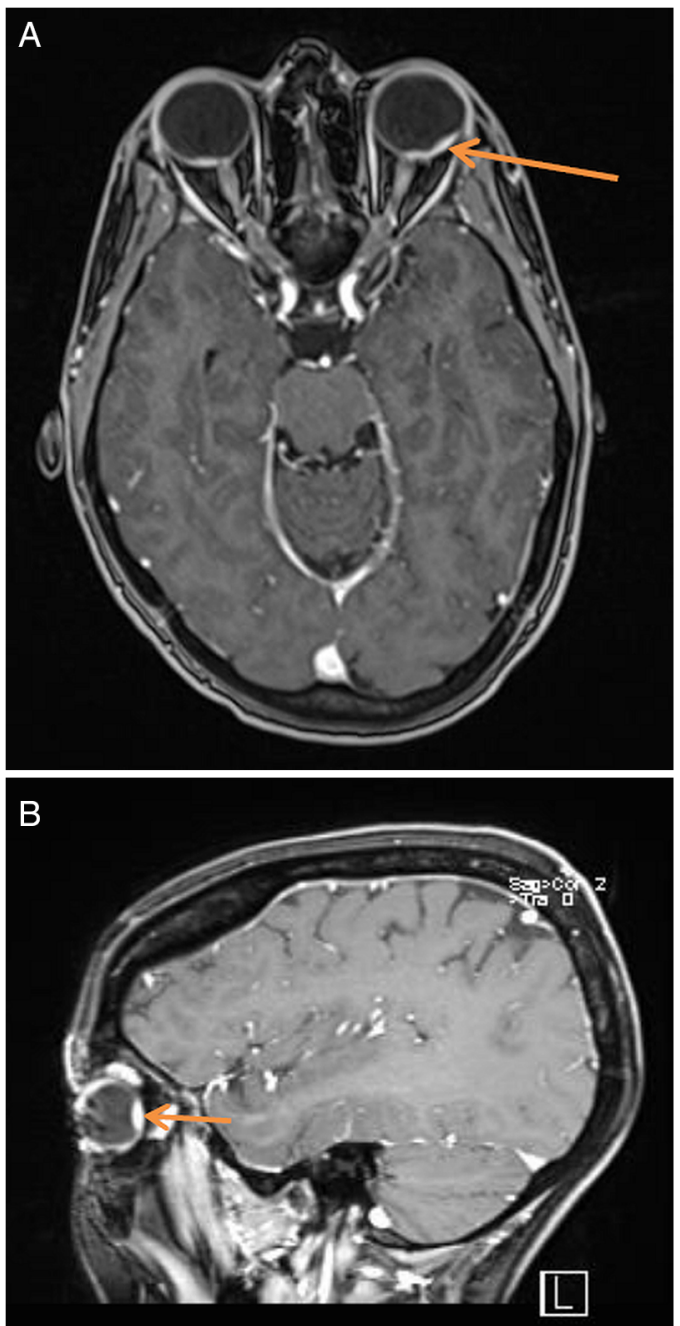

Figure 1 Brain MRI showing enhancement along the posterior surface of the bilateral globes consistent with choroidal metastases. Left globe involvement is greater than that of the right globe. (A) axial view. (B) sagittal view. also offered letrozole with goserelin but declined due to their side effect profile and risk for retinal complications.

The patient did well on routine follow-up until July 2015, when she presented to emergency department with symptoms of dizziness. Workup showed hypercalcaemia. Imaging studies including bone scan and CT scan showed multiple bone metastases, mediastinal and subcarinal lymphadenopathy and hilar masses. MRI was negative for brain lesions. Pathology from one of the lesions showed metastatic breast cancer, ER and PR positive and HER2 negative.

The patient underwent bilateral salpingooophorectomy and started gemcitabine with
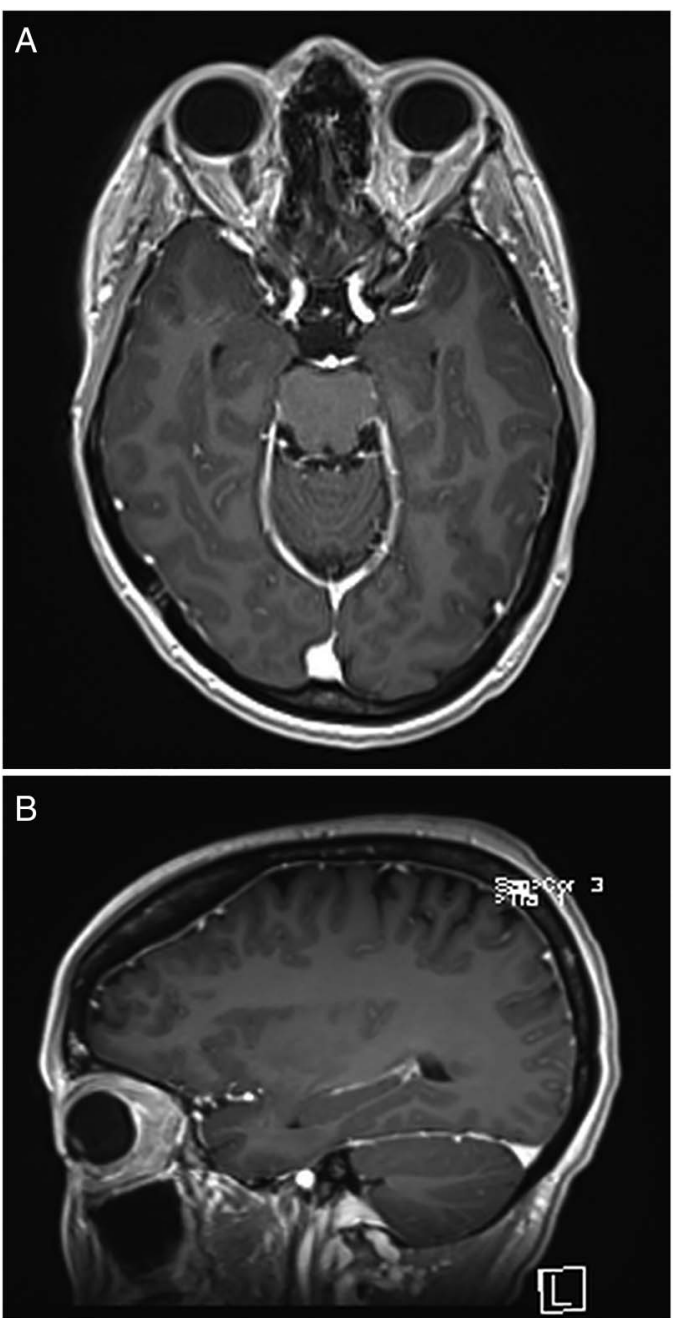

Figure 2 Brain MRI showing response to therapy with interval decrease in size of choroidal metastases. There is mild residual choroidal enhancement along the posterior lateral left globe. (A) axial view. (B) sagittal view. 
denosumab. After 2 months of therapy, she was seen by ophthalmology, for decreasing visual acuity in both eyes. Examination showed bilateral retinal masses suggestive of choroidal lesions consistent with metastatic disease. This was confirmed by MRI of the brain and orbits (figure $1 \mathrm{~A}, \mathrm{~B}$ ). Visual fields of both eyes were full. The patient had no history of diabetes mellitus, hypertension or other comorbidities. She was treated with intravitreal injections of bevacizumab $1.25 \mathrm{mg}$ and orbital radiation of $37.5 \mathrm{~Gy}$ in 14 fractions. She received the first bevacizumab injection, to the left eye, on 27 October 2015; she then received an injection to the right eye, on 6 November, and finally injections to both eyes 1 month later. Radiation therapy was administered from 16 November to 7 December 2015. The patient reported improvement in vision with the first bevacizumab injection and further recovery with the next dose, with almost complete normalisation of her vision. After completion of bevacizumab and radiation therapy, she was started on palbociclib and letrozole. Currently, she remains on this therapy and after 4 months of follow-up, her visual acuity has improved in the right eye, from $20 / 30$ to $20 / 20$ and in the left eye from $20 / 40$ to 20/30, her visual fields have continued to be full. She underwent a repeat MRI of the brain and orbits in March 2016, which showed marked improvement in both choroidal metastases (figure $2 \mathrm{~A}, \mathrm{~B}$ ).

Choroidal metastases can affect vision through different mechanisms, including direct tumour invasion into the retina and other optical structures, and increased fluid secretion caused by the tumour. Given the highly vascular nature of choroidal metastases, these lesions are likely to respond to radiation, but transiently leak more fluid in, which can be treated with antivascular endothelial growth factor intraocular injections.

This case highlights the efficacy of intravitreal bevacizumab administration in the management of subretinal fluid along with radiation therapy for choroidal metastases. While these metastases, overall, represent a rare event in breast cancer, it is important to notice the rapid improvement seen with intraocular bevacizumab, which can lead to significant gains in the patient's quality of life.

\section{Learning points}

- Choroidal metastases from breast cancer are rare and it is important to recognise that they can affect the patient's vision and quality of life.

- Novel treatments for this condition, such as intraocular bevacizumab with radiation therapy, can effectively improve the patient's symptoms by targeting the pathophysiology of subretinal fluid and metastases formation.

Acknowledgements The authors would like to thank the University of lowa Libraries for the support received for this publication.

Contributors KN prepared the manuscript. JPL revised the manuscript. Both the authors gathered the data and wrote the manuscript. Both the authors read and approved the final manuscript.

Competing interests None declared.

\section{Patient consent Obtained.}

Provenance and peer review Not commissioned; externally peer reviewed.

Open Access This is an Open Access article distributed in accordance with the Creative Commons Attribution Non Commercial (CC BY-NC 4.0) license, which permits others to distribute, remix, adapt, build upon this work non-commercially, and license their derivative works on different terms, provided the original work is properly cited and the use is non-commercial. See: http://creativecommons.org/ licenses/by-nc/4.0/

\footnotetext{
Copyright 2016 BMJ Publishing Group. All rights reserved. For permission to reuse any of this content visit http://group.bmj.com/group/rights-licensing/permissions.

BMJ Case Report Fellows may re-use this article for personal use and teaching without any further permission.

Become a Fellow of BMJ Case Reports today and you can:

- Submit as many cases as you like

- Enjoy fast sympathetic peer review and rapid publication of accepted articles

- Access all the published articles

- Re-use any of the published material for personal use and teaching without further permission

For information on Institutional Fellowships contact consortiasales@bmjgroup.com

Visit casereports.bmj.com for more articles like this and to become a Fellow
} 